\title{
SOEP
}

SOEPpapers

SOEPnanors
on Multidisciplinary Panel Data Research

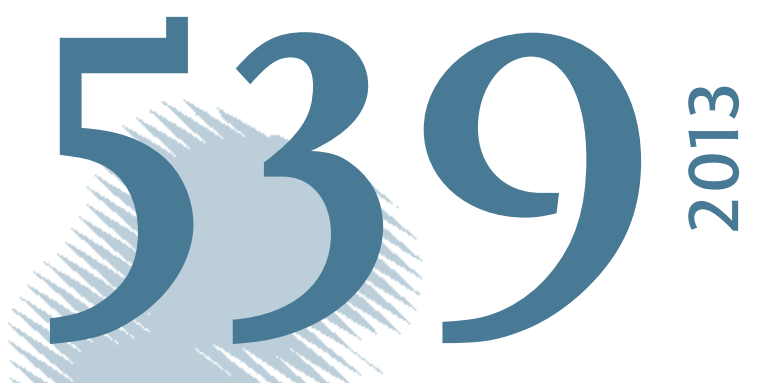

\section{Stepping Forward: Personality Traits, Choice of Profession, and the Decision to Become Self-Employed}




\section{SOEPpapers on Multidisciplinary Panel Data Research}

at DIW Berlin

This series presents research findings based either directly on data from the German SocioEconomic Panel Study (SOEP) or using SOEP data as part of an internationally comparable data set (e.g. CNEF, ECHP, LIS, LWS, CHER/PACO). SOEP is a truly multidisciplinary household panel study covering a wide range of social and behavioral sciences: economics, sociology, psychology, survey methodology, econometrics and applied statistics, educational science, political science, public health, behavioral genetics, demography, geography, and sport science.

The decision to publish a submission in SOEPpapers is made by a board of editors chosen by the DIW Berlin to represent the wide range of disciplines covered by SOEP. There is no external referee process and papers are either accepted or rejected without revision. Papers appear in this series as works in progress and may also appear elsewhere. They often represent preliminary studies and are circulated to encourage discussion. Citation of such a paper should account for its provisional character. A revised version may be requested from the author directly.

Any opinions expressed in this series are those of the author(s) and not those of DIW Berlin. Research disseminated by DIW Berlin may include views on public policy issues, but the institute itself takes no institutional policy positions.

The SOEPpapers are available at

http://www.diw.de/soeppapers

\section{Editors:}

Jürgen Schupp (Sociology, Vice Dean DIW Graduate Center)

Gert G. Wagner (Social Sciences)

Conchita D'Ambrosio (Public Economics)

Denis Gerstorf (Psychology, DIW Research Director)

Elke Holst (Gender Studies, DIW Research Director)

Frauke Kreuter (Survey Methodology, DIW Research Professor)

Martin Kroh (Political Science and Survey Methodology)

Frieder R. Lang (Psychology, DIW Research Professor)

Henning Lohmann (Sociology, DIW Research Professor)

Jörg-Peter Schräpler (Survey Methodology, DIW Research Professor)

Thomas Siedler (Empirical Economics)

C. Katharina Spieß (Empirical Economics and Educational Science)

ISSN: 1864-6689 (online)

German Socio-Economic Panel Study (SOEP)

DIW Berlin

Mohrenstrasse 58

10117 Berlin, Germany

Contact: Uta Rahmann | soeppapers@diw.de 


\title{
Stepping Forward: Personality Traits, Choice of Profession, and the Decision to Become Self-Employed
}

\author{
Michael Fritsch \\ Alina Sorgner \\ January 2013
}

\begin{abstract}
We argue that entrepreneurial choice proceeds in at least in two steps, with vocational choice nearly always preceding choice of employment status, whether that be self-employment or dependent employment. Since the two decisions are interrelated, analysis of entrepreneurial choice as a single act may lead to inconsistent estimates of the factors that determine the decision to launch a business venture. Our empirical analysis utilizes a bivariate probit model that jointly estimates both decisions. The results support our argument that entrepreneurial choice is a two-stage decision process.

JEL classification: L26, J24, D01
\end{abstract}

Keywords: $\quad$ Entrepreneurial choice, vocational choice, personality traits

Address for correspondence:

Michael Fritsch

Alina Sorgner

Friedrich Schiller University Jena

School of Economics and Business Administration

Chair of Business Dynamics, Innovation, and Economic Change

Carl-Zeiss-Str. 3, D-07743 Jena, Germany

m.fritsch@uni-iena.de

alina.sorgner@uni-jena.de 


\section{Introduction}

The most common model of entrepreneurial choice (Knight, 1921; Lucas, 1978; Kihlstrom and Laffont, 1979) considers the decision to start an own firm as a single act and therefore does not adequately account for the dynamic character of entrepreneurship. However, the ability and willingness to start an own business do not just happen overnight, but develop over a period of time based on individual disposition, qualifications, experience, and, maybe, necessity, such as lack of an alternative source of income (Parker, 2009; SchmittRodermund, 2007; Obschonka, Silbereisen and Schmitt-Rodermund, 2010). The common pattern is that people first train for and work in a certain occupation before they decide to become self-employed (Fritsch, Kritikos and Rusakova, 2012). Accordingly, the decision to start an own firm may be partly the result of an individual's previous career choices. Due to such interrelatedness with previous decisions, analysis of entrepreneurial choice as a single act may lead to inconsistent estimates of the factors that determine the decision to found an own business.

In this paper we argue that entrepreneurial choice is a two-stage process, in which the choice of a certain profession made early in life significantly influences the decision to become self-employed in the future. Specifically, we discuss possible reasons for interrelatedness between the choice of a certain profession and the decision to be selfemployed, stressing two main arguments in favor of such interrelatedness. The first (self-selection hypothesis) states that people with pronounced entrepreneurial attitudes tend to self-select into certain professions that might foster development of their entrepreneurial talent. The second hypothesis (endowment hypothesis) conjectures that the characteristics of an occupational environment may stimulate the development of entrepreneurial skills and attitudes even in people whose personality is not inherently entrepreneurial. In our empirical 
setting we apply a bivariate probit model to representative data from the German Socio-Economic Panel (SOEP) and find support for both hypotheses, suggesting that the choice of a certain occupation and the decision to become self-employed are indeed interrelated.

The paper proceeds as follows. Section 2 sets out our basic argument concerning the relationship between vocational choice and entrepreneurial choice. Section 3 introduces the instrumental variable approach that allows us to estimate the two interrelated choices. Section 4 introduces the data and methodology. The results of the analysis are presented in Section 5. Section 6 concludes and discusses avenues for further research.

\section{Entrepreneurial choice as a two-stage decision process}

Chronologically, choosing a profession (vocational choice) nearly always occurs before deciding to set up an own business. The relationship between vocational choice and entrepreneurial choice may have two main forms. First, pro-entrepreneurial people with certain personality traits such as the ability to bear risk, openness to experience, and so forth (Caliendo, Fossen and Kritikos, 2009; Zhao and Seibert, 2006; Zhao, Seibert and Lumpkin, 2010; Rauch and Frese, 2007; Sorgner, 2012) may choose a profession that requires and rewards entrepreneurial values and provides rich opportunities for selfemployment. Second, individuals who do not choose their profession with any intention of setting up an own business may be stimulated toward entrepreneurship while training for and working in such a profession. This kind of effect may occur through the acquisition of entrepreneurial skills, contact with entrepreneurial role models, becoming embedded in a professional network, becoming aware of entrepreneurial opportunities, or by experiencing poor employment and earning opportunities in dependent employment (Sorgner and Fritsch, 2013). Figure 1 shows the interplay of different factors that may influence both the choice of a profession and entrepreneurial choice. 


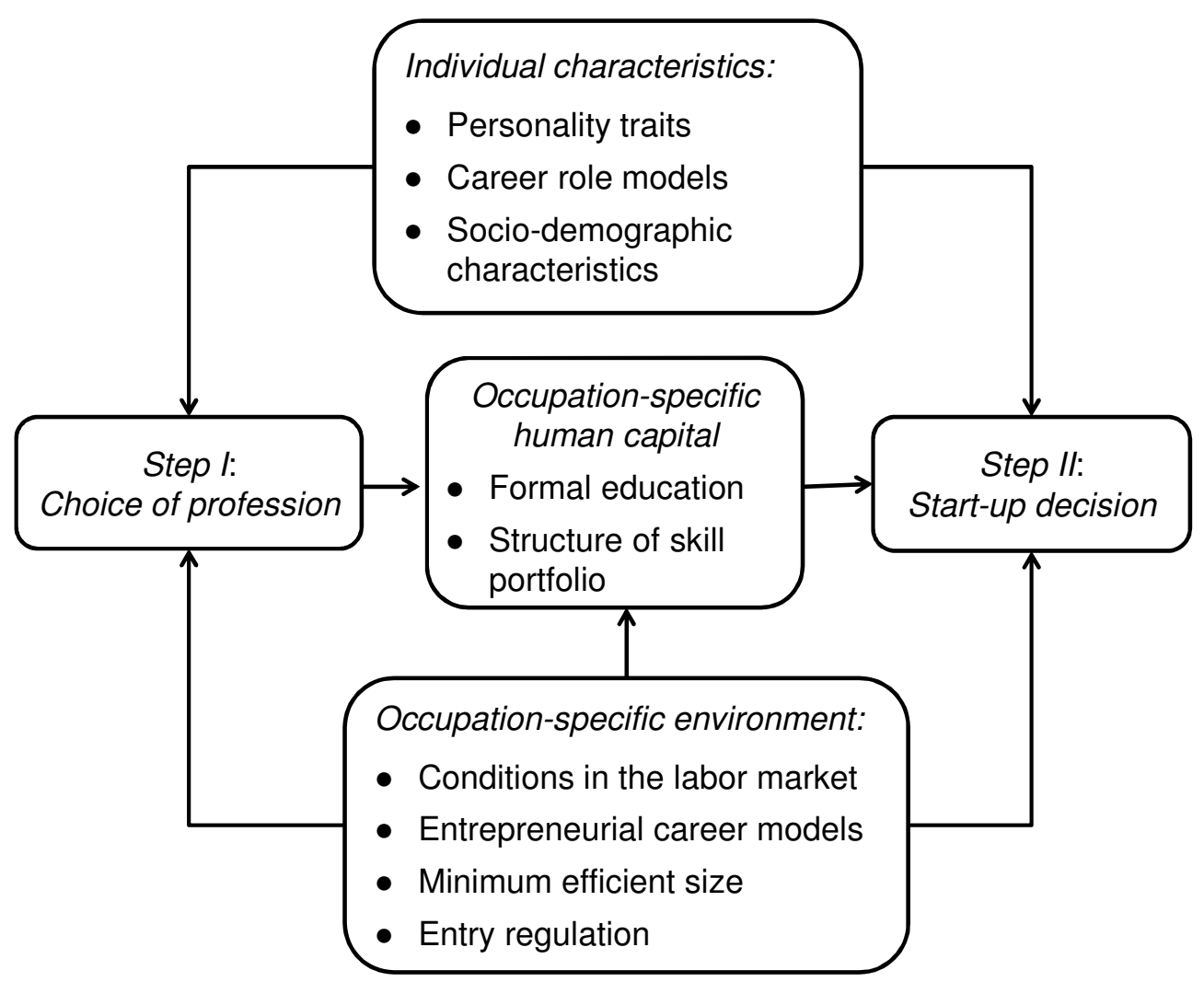

Figure 1: Entrepreneurial choice as a two-stage decision process.

Factors often regarded as motivation to launch an own business, such as wanting to earn more money, a wish for more independence and flexibility, and a desire for more creative work, among others, may also guide vocational choice. Hence, people with an entrepreneurial mindset may be likely to choose occupations that match their preferences. For instance, someone with a strong motivation to earn money will be more likely to enter an occupation that offers relatively high earnings (Sorgner and Fritsch, 2013). Similarly, people who enjoy independence and a creative work environment may choose an artistic occupation. And, indeed, research shows that people with entrepreneurial personality traits (e.g., high levels of openness to experience, conscientiousness, extraversion, and low degrees of neuroticism and agreeableness) are more likely to be interested in so- 
called enterprising occupations, such as management, sales, and finance, and are relatively often found in artistic occupations (e.g., musician, artist, architect) (Schmitt-Rodermund, 2004; Sorgner, 2012).

The fact that the majority of start-ups occur after the founder has spent some time in dependent employment (Fritsch, Kritikos and Rusakova, 2012) suggests that occupational environment may have a considerable impact on an individual's decision to become selfemployed (Sorgner and Fritsch, 2013). One aspect of occupational environment that might have such an influence is the variety of skills required. According to the "jack of all trades" hypothesis (Lazear, 2004, 2005), work environments characterized by high task complexity and that require a great number of different skills should be especially conducive to self-employment. Indeed, Fritsch, Bublitz and Rusakova (2012) show that occupational environments vary greatly with regard to the skill balance of the people working in them, which may partly explain differences in start-up rates across occupations. Specifically, people in occupations that require high levels of human capital (e.g., engineers, chemists, physicists, natural scientists, managers) tend to also have high skill balance, whereas unskilled workers, such as street vendors, cleaners, or delivery service drivers, generally have rather low skill balance levels.

Occupational environment may also be conducive to an individual's decision to become an entrepreneur if a great many entrepreneurs already work in the occupation, thereby providing role models for this career path. For instance, people in professions with relatively high selfemployment rates, such as medicine, law, and art, are more often exposed to examples of an entrepreneurial career in their profession as compared to people in professions characterized by a lower level of self-employment. Observing self-employed peers and colleagues is found to have a strong effect on an individual's propensity to become self-employed (Nanda and Sorensen, 2010; Bosma et al., 2012). The presence of established entrepreneurial businesses in many of the 
liberal professions, for example, self-employed physicians, lawyers, and tax consultants, are recognized and relatively easily reproducible models. Moreover, such standardized entrepreneurial opportunities may be easier to "sell" to financiers. Furthermore, entry regulations in certain professions, such as physicians, psychotherapists, and lawyers, may result in a considerably lower risk of failure when starting an own firm. Indeed, people who work in occupations characterized by high levels of self-employment are more likely to become self-employed themselves (Sorgner and Fritsch, 2013). Another characteristic of many professions with high levels of self-employment, and one that may be especially conducive to starting an own business, is small minimum efficient size, thus requiring low initial investment (Figure 1).

Poor economic conditions in the occupation-specific labor market, such as scarcity of jobs, low income in dependent employment, and high levels of unemployment, may influence a person's entrepreneurial choice even if he or she had no original intentions of becoming selfemployed. It is plausible to assume that many people are well aware of the opportunities available in the occupation-specific labor market when making their vocational choice. During training for and working in a chosen occupation, people acquire specific human capital that is often hardly transferable across occupations (Gathmann and Schönberg, 2010). Hence, if economic conditions in the occupation-specific labor market change, the costs associated with re-qualification might prevent people from switching to another occupation with different qualification requirements (Nedelkoska and Neffke, 2010), making a switch into selfemployment in the given occupation relatively attractive. Sorgner and Fritsch (2013) indeed find that occupation-specific unemployment rates are positively associated with the propensity to become self-employed.

All in all, there are numerous indications that entrepreneurial choice does not occur in one stage, but that it involves at least two decisions, including the choice of profession. The choice of profession and the decision to start an own business may be interrelated in two ways. First, 
people with a strong desire to become self-employed may choose professions that make it more feasible to set up an own business. Second, people may first choose a profession that matches their interests, personalities, and preferences independent of any intention of future self-employment but then, later on, based on the experience they gain in this profession, decide to become self-employed. Hence, there are good reasons to expect that there is a causal relationship between professional and entrepreneurial choices.

In this dynamic process, the choice of a profession may be viewed as an advance decision for or against self-employment. If, however, the decisions are interrelated, analysis of entrepreneurial choice as a single act may lead to inconsistent estimates of the factors that determine the decision to launch a business venture. Hence, a correct estimation of the model of entrepreneurial choice needs to account for the choice of a profession.

\section{The effect of the choice of profession on entrepreneurial choice: An instrumental variable approach}

The arguments presented above suggest that there is a causal relationship between professional and entrepreneurial choice. However, trying to account for such a two-stage entrepreneurial choice by simply including profession as an independent variable in an empirical model may not solve the problem since there could be unobservable characteristics that are correlated with both the choice of profession and entrepreneurial choice. To test the relevance of this concern, we apply an instrumental variables approach that should allow us to identify the causal effect. We instrument an individual's choice of profession with that practiced by his or her father when the individual was about 15 years old. A causal interpretation of the relationship between the choice of a profession and entrepreneurial choice requires that the instrument is relevant and independent of the outcome variable (respondent's entrepreneurial choice). 
An instrument is appropriate if it is correlated with the endogenous variable, in our case, the respondent's choice of a profession. There are numerous studies finding a pronounced tendency for intergenerational occupation following, that is, children choose the same occupation as their parents (Jonsson et al., 2009; Laband and Lentz, 1983, 1989; Karlsson and Stanfors, 2011). Laband and Lentz (1983) argue that a main reason for occupation following is the transfer of occupationrelated skills and reputation from parents to children. Since occupation is an important part of person's identity, parents might foster the taste for a certain occupation in their children. A cross-national study by Jonsson et al. (2009) finds that occupational inheritance is particularly strong in Germany, which may be due to the well-developed system of vocational training in this country, leading to a considerable accumulation of occupation-specific skills and thus to a strong commitment to one's occupation and a willingness to transfer one's occupational identity to one's children. Occupation following may also result from the selection processes of training institutions given that these sometimes favor students who come from families already active in the chosen profession. Indeed, Laband and Lentz (1989) show that children of medical doctors are more likely to be admitted to medical school compared to children of parents in non-medical professions, and this was discovered to be at least partly due to personal networks and nepotism.

Another necessary condition for an instrument variable is its independence of the outcome variable. Empirical evidence suggests that a child's self-employment status is independent of the father's occupation. In particular, Dunn and Holtz-Eakin $(2000,290)$ show that self-employed sons were as likely as never-self-employed sons to follow their father's occupation. Moreover, the authors reveal that the majority of self-employed sons in their data entered occupations others than those of their (self-employed or non-self-employed) fathers. Additionally, those people who do not follow in their parents' 
occupational footsteps often use self-employment as a way of moving up the socioeconomic status ladder (Katz, 1992). Finally, unwillingness to follow the father's occupation may be related to rule-breaking behavior in adolescence, which involves defying parental authority and expectations. Rule breaking in adolescence, in turn, is shown to be positively associated with entrepreneurial status (Zhang and Arvey, 2009). Thus, it appears plausible that occupation followers are not more likely to be self-employed than non-occupation followers. Overall, our instrument appears to fulfill the necessary conditions. We provide additional proof of the independence of our outcome variable from the instrument in Section 5.1.

\section{Data and methodology}

\subsection{Sample and measures}

Our empirical analysis is based on the German Socio-Economic Panel (SOEP), a representative longitudinal study of private households in Germany (for details, see Wagner, Frick and Schupp, 2007). For the present analysis, we use the 2009 wave of the survey because the full set of independent variables, including information on personality characteristics, was available in this particular year. The 2009 wave of the SOEP provides data on about 21,000 individuals living in Germany. We exclude persons who were retired, unemployed, or engaged in fulltime education. We also exclude civil servants and those in military service since we consider the choice of profession for these groups to be different from that of employees in the private sector. Self-employed farmers and employees in the agricultural sector are excluded for the same reason. ${ }^{1} \mathrm{Next}$, all persons who stated that their primary activity is helping in a family business are omitted because of their mixed status of being neither "full" entrepreneurs nor "pure" dependent employees.

\footnotetext{
${ }^{1}$ Most farms in Germany are family businesses so that their owners are more or less self-employed by definition. Thus, the self-employment of farmers may be a result of a either family or regional tradition.
} 
After excluding respondents with missing values for relevant information, our sample includes 5,100 persons, 630 (12.4 percent) of whom are self-employed in their main occupation.

A key variable in our analysis is an individual's profession. The information on individuals' professions is available at the four-digit level of the International Classification of Occupations (ISCO-88; for details, see International Labour Office, 1990). To have a sufficiently large number of cases for analysis, we create eight groups of professions that correspond to the two-digit level of ISCO-88 (Table 1). In this classification scheme, occupations are aggregated on the basis of similarity of skills required to fulfill the tasks and duties of the jobs and not according to the level of professional hierarchy that individuals achieved. Hence, older persons who may have achieved a high position, such as director, are in the same category as beginners in that

Table 1: Sample occupations

\begin{tabular}{|c|c|c|}
\hline Occupational group: & $\begin{array}{l}\text { 2-digit } \\
\text { ISCO-88 } \\
\text { codes }\end{array}$ & Description \\
\hline Managers & $11-13$ & $\begin{array}{l}\text { Directors, chief executives, department managers, } \\
\text { general managers }\end{array}$ \\
\hline $\begin{array}{l}\text { Physical, mathematical, } \\
\text { and engineering science } \\
\text { professionals }\end{array}$ & 21,31 & $\begin{array}{l}\text { Physicists, mathematicians, computing professionals, } \\
\text { architects, engineers, technicians, and associate } \\
\text { professionals }\end{array}$ \\
\hline $\begin{array}{l}\text { Life science and health } \\
\text { professionals }\end{array}$ & 22,32 & Medical doctors, veterinarians, pharmacists, biologists \\
\hline Teaching professionals & 23,33 & $\begin{array}{l}\text { College, university, and higher education teaching } \\
\text { (associate) professionals }\end{array}$ \\
\hline Other professionals & 24,34 & $\begin{array}{l}\text { Business professionals, legal professionals, social } \\
\text { science professionals, writers, and creative or } \\
\text { performing artists }\end{array}$ \\
\hline Service workers & 51,52 & $\begin{array}{l}\text { Travel attendants, housekeepers, cooks, personal care } \\
\text { workers, hairdressers, protective service workers }\end{array}$ \\
\hline Trades workers & $71-74$ & $\begin{array}{l}\text { Roofers, painters, miners, builders, musical instrument } \\
\text { makers, bookbinders, shoemakers }\end{array}$ \\
\hline Elementary occupations & $\begin{array}{l}41,42,81- \\
93\end{array}$ & $\begin{array}{l}\text { Office clerks, customer services clerks, machine } \\
\text { operators and assemblers, drivers, sales and service } \\
\text { elementary occupations }\end{array}$ \\
\hline
\end{tabular}


particular profession. The same occupational classification scheme is used to identify the profession of a respondent's father when the respondent was 15 years old.

Previous empirical analyses of the determinants of self-employment find a significant impact of various human and social capital, sociodemographic characteristics, and the macro environment on the probability of running an own business (see Parker, 2009). In our model, we account for these influences to the extent that appropriate indicators are available in the data. The set of available control variables includes age, gender, marital status, nationality, years of formal education, years of unemployment, parental role models of selfemployment at age of 15 , and region in which a person resides. Since the 2009 wave of the SOEP data contains questions on the Big Five dimensions of personality, we are able to control for personality traits. ${ }^{2}$ Furthermore, we include a measure of risk preferences in our analysis, since entrepreneurs are commonly regarded as risk-takers (Caliendo, Fossen and Kritikos, 2009). The measure of risk attitudes in SOEP is an experimentally validated measure based on the question "Are you generally a person who is fully prepared to take risks or do you try to avoid taking risks?" (Dohmen et al., 2011). A description of all variables used in the analysis, as well as the correlation matrix, can be found in Tables A1 and A2 in the Appendix.

\subsection{Methodology: The bivariate probit model}

In the empirical analysis, we employ a bivariate probit model (Greene, 2008) for a joint estimation of the two interrelated choices-choice of

\footnotetext{
${ }^{2}$ These questions refer to a psychological scale that measures the Big Five factors (Costa and McCrae, 1992) based on three questions for each of the broad dimensions. The SOEP respondents were asked to rate themselves on a seven-point scale, with 1 indicating that a given personality characteristic does not apply to them at all and 7 meaning that the characteristic applies perfectly. The value for each of the Big Five dimensions is an arithmetical mean of the responses to the related three questions. A detailed description of the procedure used in the SOEP survey can be found in Gerlitz and Schupp (2005). The authors show that self-reported personal attitudes based on the Big Five related questions in the SOEP are valid and reliable.
} 
profession and decision to be self-employed-in order to obtain consistent estimates of coefficients. ${ }^{3}$

Consider the model,

$y_{1}^{*}=\beta_{1}^{\prime} x_{1}+\gamma^{(k)} y_{2}^{(k)}+\varepsilon_{1}$,

$y_{2}^{*(k)}=\beta_{2}^{\prime} x_{2}+\varepsilon_{2}$,

where $y_{1}^{*}$ and $y_{2}^{*(k)}$ are latent variables. We observe:

$\left\{\begin{array}{l}y_{1}=1, \quad \text { if } \quad y_{1}^{*}>0, \quad 0 \quad \text { otherwise, } \\ y_{2}^{(k)}=1, \quad \text { if } \quad y_{2}^{*(k)}>0, \quad 0 \quad \text { otherwise. }\end{array}\right.$

The dependent variable, $y_{1}$, is equal to 1 if the individual decides to be self-employed; 0 otherwise. The variable, $y_{2}^{(k)}$, assumes the value 1 if an individual chooses profession $k, k \in \overline{1, N}$, and 0 otherwise; $x_{1}$ and $x_{2}$ are vectors of explanatory variables, $\beta_{1}^{\prime}$ and $\beta_{2}^{\prime}$ are parameter vectors. We are interested in estimating the scalar parameter $\gamma^{(k)}$, which indicates the impact of the predicted probability of an individual to be in profession $k$ on the likelihood of being self-employed. The error terms $\varepsilon_{1}$ and $\varepsilon_{2}$ are assumed to be jointly normally distributed with

$\mathrm{E}\left(\varepsilon_{1} \mid x_{1}, x_{2}\right)=\mathrm{E}\left(\varepsilon_{2} \mid x_{1}, x_{2}\right)=0$,

$\operatorname{Var}\left(\varepsilon_{1} \mid x_{1}, x_{2}\right)=\operatorname{Var}\left(\varepsilon_{2} \mid x_{1}, x_{2}\right)=1$,

$\operatorname{Corr}\left(\varepsilon_{1}, \varepsilon_{2} \mid x_{1}, x_{2}\right)=\rho$,

and the joint density of the error terms is given by

\footnotetext{
${ }^{3}$ A modification of a bivariate model, a recursive bivariate probit model, is discussed and applied empirically in several studies (see, e.g., Greene, 1998, 2008;

Bauernschuster, Falck, and Heblich, 2009; Fabbri and Monfardini, 2008; Kassouf and Hoffmann, 2006; Rhine, Greene, and Toussaint-Comeau, 2006).
} 
$\phi\left(\varepsilon_{1}, \varepsilon_{2}\right)=\frac{1}{2 \pi \sigma_{\varepsilon_{1}} \sigma_{\varepsilon 2} \sqrt{1-\rho^{2}}} \exp \left[-\frac{1}{2}\left(\frac{\varepsilon_{1}^{2}+\varepsilon_{2}^{2}-2 \rho \varepsilon_{1} \varepsilon_{2}}{1-\rho^{2}}\right)\right]$

If $\rho=0$, the equations in (1) are not interrelated and thus can be estimated separately using a univariate probit model. If $\rho \neq 0$, the joint estimation of both equations using the bivariate probit model will provide consistent parameter estimates.

\section{Results}

\subsection{Descriptive statistics}

We find a number of statistically significant differences between the self-employed and the reference group of dependently employed individuals in our sample (Table 2 ). ${ }^{4}$ With regard to regional environment, we find that the average propensity for self-employment is significantly higher in large agglomerations and significantly lower in urbanized regions. However, there is no statistically significant difference between self-employed and dependently employed people in rural areas. On average, self-employed persons had 14.1 years of education, which is significantly more than the average 12.7 years of education of the dependently employed. Moreover, about 19.2 percent of self-employed persons had self-employed parents when they were 15 years old; this figure is 8.9 percent for the dependently employed. Self-employed individuals in the sample are more likely to be married (68.7 percent) than are employees (60.3 percent) and there is a significantly higher share of males in the group of self-employed (64.6 percent) than in the group of dependently employed (50.7 percent). The average age of self-employed persons in the sample is about 48.2 years old, which is about 6 years more than the average age of employees.

\footnotetext{
${ }^{4}$ For descriptive statistics of all variables, see Table A2 in the Appendix.
} 
Table 2: Mean characteristics and t-test of equal means for selfemployed individuals compared to the reference group

\begin{tabular}{|c|c|c|}
\hline Variable: & Self-employed & $\begin{array}{l}\text { Dependently } \\
\text { employed }\end{array}$ \\
\hline Agglomerations & $0.565^{* * *}$ & 0.492 \\
\hline Urbanized regions & $0.321^{* * *}$ & 0.377 \\
\hline Rural areas & 0,114 & 0.131 \\
\hline Years of education & $14.084^{\star \star \star}$ & 12.699 \\
\hline Years unemployed & $0.496^{*}$ & 0.618 \\
\hline $\begin{array}{l}\text { Either parent self-employed } \\
(\text { yes }=1, \text { no }=0)\end{array}$ & $0.192^{* \star *}$ & 0.089 \\
\hline Married $($ yes $=1$, no $=0$ ) & $0.687^{* \star *}$ & 0.603 \\
\hline Male $($ yes $=1$, no $=0)$ & $0.646^{* * *}$ & 0.507 \\
\hline German $($ yes $=1$, no $=0)$ & 0,960 & 0.953 \\
\hline Age & $48.195^{\star \star \star}$ & 42.274 \\
\hline Openness & $4.854^{\star \star \star}$ & 4.417 \\
\hline Conscientiousness & $5.964^{\star *}$ & 5.882 \\
\hline Extraversion & $5.012^{* * *}$ & 4.817 \\
\hline Agreeableness & 5,275 & 5.257 \\
\hline Neuroticism & $3.506^{* * *}$ & 3.739 \\
\hline Willingness to take risks & $4.557^{* \star *}$ & 4.040 \\
\hline Number of observations & 630 & 4,470 \\
\hline
\end{tabular}

Notes: ${ }^{* * *}$ : statistically significant at the $1 \%$ level; ${ }^{* *}$ : statistically significant at the $5 \%$ level; *: statistically significant at the $10 \%$ level.

As Figure 2 shows, self-employment is not equally distributed across the different groups of professions. The highest average probabilities of self-employment are in professions such as management (30.8 percent), teaching (18.1 percent), and life science and health (17.8 percent). The lowest average probabilities of selfemployment are in elementary occupations such as office and customer service clerks (2.7 percent) and service workers and sales $(7.5$ percent). 


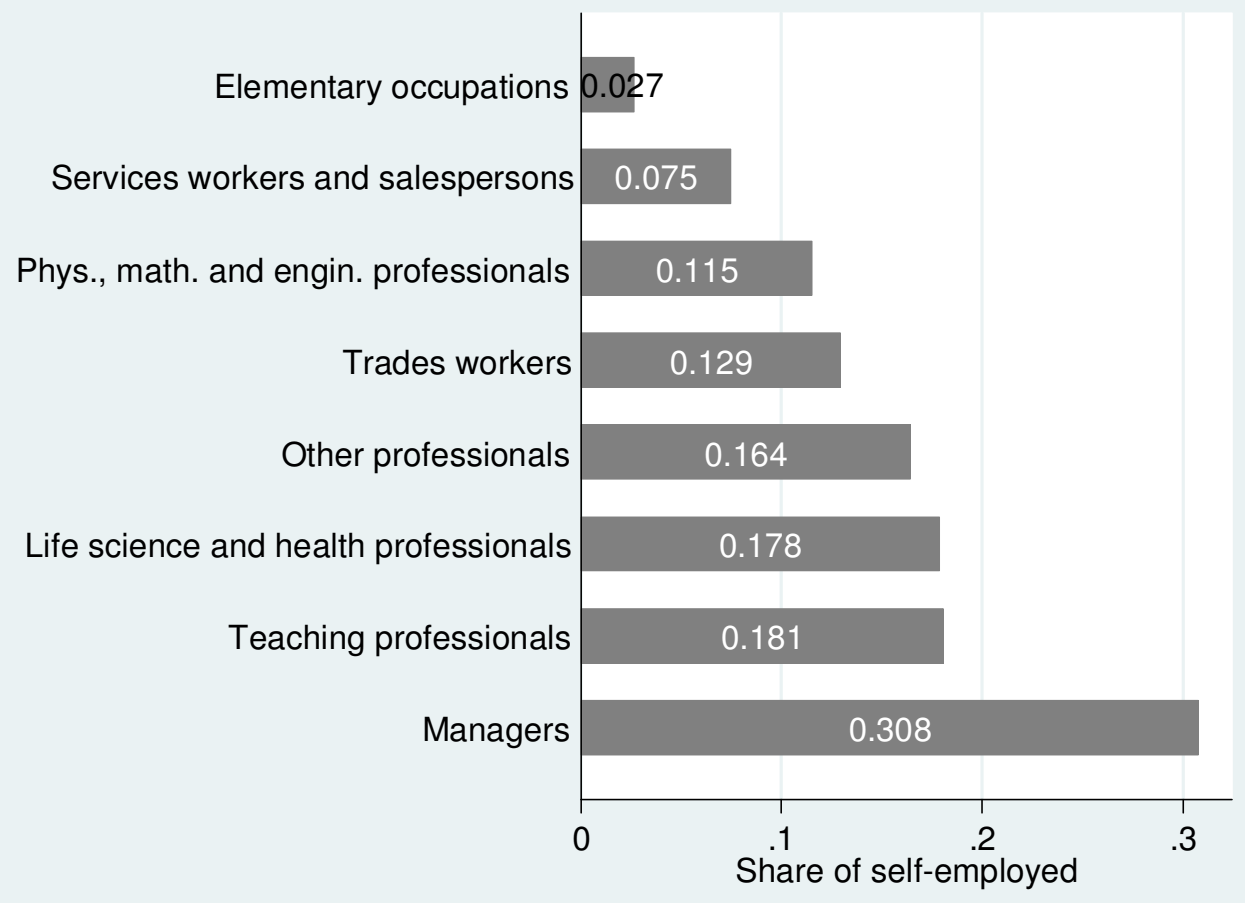

Figure 2: Shares of self-employed across occupations

Table 3: Occupational role models

\begin{tabular}{lccc}
\hline & $\begin{array}{c}\text { Number of } \\
\text { respondents in } \\
\text { occupation }\end{array}$ & $\begin{array}{c}\text { Father was in the } \\
\text { same occupation }\end{array}$ & Share, \% \\
\hline Managers & 364 & 63 & $17,31 \%$ \\
$\begin{array}{l}\text { Physicists, mathematicians, } \\
\text { and engineering professionals }\end{array}$ & 635 & 113 & $17,80 \%$ \\
$\begin{array}{l}\text { Life science and health } \\
\text { professionals }\end{array}$ & 342 & 25 & $7,31 \%$ \\
$\begin{array}{l}\text { Teaching professionals } \\
\text { Other professionals }\end{array}$ & 249 & 19 & $7,63 \%$ \\
Service workers & 1.116 & 206 & $18,46 \%$ \\
Trades workers & 549 & 20 & $3,64 \%$ \\
Elementary occupations & 641 & 301 & $46,96 \%$ \\
\hline Total & 1.204 & 384 & $31,89 \%$ \\
\hline
\end{tabular}


With regard to the relevance of our instrument variable, we find that 22.2 percent of the individuals in our sample have followed the occupational pattern of their fathers (Table 3). However, occupation followers are unevenly distributed across the groups of professions. The highest share (almost 47 percent) of those choosing their father's profession is in the group of trades workers. High shares of occupation followers are also observed among elementary occupations (32 percent) that involve simple and routine tasks and in the group of "other professionals" (18.5 percent). The lowest share of occupation followers is among service workers (3.6 percent). This relatively low share of intergenerational transmission among service workers may be partly explained by the recent expansion of the service sector, which may have offered employment opportunities to a wide spectrum of the population, not only those whose fathers worked in the service sector.

Proving the instrumental variable's independence from the outcome variable is much more challenging than demonstrating the relevance of the instrument. For instance, one possible concern about our instrument variable is that occupation followers of self-employed fathers may be more likely to be self-employed themselves because they might be qualified enough to take over a family business or just because they are more prone to have the same occupational tastes as their fathers, including the attitude toward self-employment. Hence, to gain some insight into whether occupation followers are more likely to be selfemployed we conduct a probit regression analysis (Table 4). The binary dependent variable indicates whether a person has chosen the profession her or his father had when the person was 15 years old (yes $=1$, no $=0$ ), and the independent variables are the child's selfemployment status (self-employed vs. employee), father's selfemployment status when the respondent was about 15 years old, and a set of control variables, including personality traits. The results suggest that neither the self-employment status of a child nor the self- 
Table 4: Determinants of occupational following

\begin{tabular}{|c|c|c|}
\hline $\begin{array}{l}\text { Dependent variable: occupational following (yes }=1 \text {, no } \\
=0 \text { ) }\end{array}$ & Coefficient & $\begin{array}{l}\text { Standard } \\
\text { error }\end{array}$ \\
\hline Self-employed $($ yes $=1$, no $=0$ ) & 0.075 & $(0.062)$ \\
\hline Either parent self-employed $($ yes $=1$, no $=0$ ) & 0.061 & $(0.065)$ \\
\hline Age & 0.000 & $(0.013)$ \\
\hline Age, squared & 0.000 & $(0.000)$ \\
\hline Male $($ yes $=1$, no $=0)$ & $0.418^{* * *}$ & $(0.043)$ \\
\hline Married $($ yes $=1$, no $=0$ ) & 0.004 & $(0.044)$ \\
\hline Conscientiousness & -0.009 & $(0.024)$ \\
\hline Extraversion & 0.027 & $(0.019)$ \\
\hline Agreeableness & -0.018 & $(0.021)$ \\
\hline Openness & $-0.033^{* * *}$ & $(0.019)$ \\
\hline Neuroticism & 0.018 & $(0.017)$ \\
\hline German nationality (yes $=1, \mathrm{no}=0$ ) & -0.131 & $(0.090)$ \\
\hline Years of education & $-0.025^{\star \star \star}$ & $(0.008)$ \\
\hline Intercept & -0.433 & $(0.360)$ \\
\hline Number of observations & 5,100 & \\
\hline$R^{2}$ & 0.025 & \\
\hline Wald chi ${ }^{2}$ & $124.89^{* * *}$ & \\
\hline Log-likelihood & $-2,630.87$ & \\
\hline
\end{tabular}

Notes: Results of a probit regression. The dependent variable equals 1 if the respondent has the same occupation that his or her father had when the respondent was 15 years old; 0 otherwise. Robust standard errors in parentheses. ${ }^{* * *}$ : statistically significant at the $1 \%$ level; **: statistically significant at the $5 \%$ level; *: statistically significant at the $10 \%$ level.

employment status of her or his parents has a statistically significant association with the probability of being an occupation follower. Interestingly, those people with high scores on the "openness to experience" scale, which is an important trait for an entrepreneur (Schmitt-Rodermund, 2007; Sorgner, 2012), are significantly less likely to be occupation followers. Thus, we found no indication that 
occupation following is associated with the probability of selfemployment and we therefore regard our instrument variable as an independent one.

\subsection{Multivariate analysis}

Following the model described in previous section, $y_{1}$ equals 1 if a person is self-employed and equals 0 if a person is dependently employed; $y_{2}^{(k)}$ equals 1 for persons whose profession is $k, k \in \overline{1,8}$ and equals 0 otherwise; $x_{1}$ is a vector of explanatory variables that comprises all variables reported in Table 2, i.e., those factors that appear to have a significant association with the probability of selfemployment.

The literature identifies a number of factors that might be associated with the choice of profession. For instance, the theory of vocational behavior (Holland, 1985; Schneider, 1987) argues that choice of profession is an expression of one's personality and, indeed, several empirical studies show a relationship between personality and choice of a particular vocation (Filer, 1986; Borghans et al., 2008; Sorgner, 2012). Moreover, certain professions continue to be either male or female dominated. And, as discussed above, family occupational role models may have an important influence on a child's vocational choice. Thus, $x_{2}$, the vector of explanatory variables in the second equation in (1), includes the Big Five traits, willingness to take risks, gender, parental self-employment status when the respondent was 15 years old, and a dummy variable indicating whether a person has the same profession as his or her father had when the respondent was 15 years old.

We first estimate a univariate probit model of self-employment that includes all variables in $x_{1}$ and a dummy variable for each of the eight groups of professions (Table 5). The results indicate a statistically 
significant effect of profession on the probability of self-employment in six of the eight groups. We find a positive effect of profession on the probability of being self-employed for managers, life science and health professionals, trades workers, and other professions. In physical, mathematical, and engineering science professions, as well as in elementary occupations, this effect is significantly negative, indicating a relatively low propensity for self-employment. No statistically significant relationships are found for teaching professionals or service workers.

As these estimates may be inconsistent due to possible interdependency of the choice of profession and self-employment status, the bivariate probit model is estimated in the next step (Table 6). A first important result of the bivariate probit regression is that $\rho$ is significantly different from zero in model specifications for managers, physical, mathematical, and engineering professionals, other professionals, service workers, and elementary occupations. Thus, the choice of one of these professions and entrepreneurial choice are interrelated. However, $\rho$ is not significantly different from zero in models for life science and health professionals, teachers, and trades workers. This means that the choice of one of these professions and self-employment choice are not interrelated, and one must interpret the corresponding results from the univariate probit model (Table 5).

Concerning our instrument variable, we find that the profession of the respondent's father when the respondent was 15 years old strongly determines the respondent's choice of profession. This effect is statistically significant for all professional groups except service workers. Moreover, the results of the bivariate probit model are quite different from those of the univariate probit model. For instance, in the univariate probit model, being a manager had a positive effect on the probability of self-employment (Table 5), but we now observe that the predicted probability of being a manager has no significant effect on the 
Table 5: Results of a univariate probit regression for the probability of self-employment in the full sample with dummy variables indicating a type of profession

\begin{tabular}{|c|c|c|c|c|c|c|c|c|}
\hline & 1 & II & III & IV & $\mathrm{V}$ & $\mathrm{VI}$ & VII & VIII \\
\hline Variables: & $\mathrm{k}=$ Managers & $\begin{array}{c}\text { k=Physical, } \\
\text { mathematical, } \\
\text { engineering } \\
\text { science profes- } \\
\text { sionals }\end{array}$ & $\begin{array}{l}\mathrm{k}=\text { Life science } \\
\text { and health } \\
\text { professionals }\end{array}$ & $\begin{array}{l}\mathrm{k}=\text { Teaching } \\
\text { professionals }\end{array}$ & $\begin{array}{l}\mathrm{k}=\text { Other profes- } \\
\text { sionals }\end{array}$ & $\begin{array}{l}\mathrm{k}=\text { Service } \\
\text { workers }\end{array}$ & $\begin{array}{c}\mathrm{k}=\text { Trades } \\
\text { workers }\end{array}$ & $\begin{array}{l}\text { k=Elementary } \\
\text { occupations }\end{array}$ \\
\hline \multirow[t]{2}{*}{ Dummy: $=1$ if profession $=k$} & $0.526^{\star \star \star}$ & $-0.319^{\star * \star}$ & $0.221^{\star \star}$ & 0.125 & $0.161^{\star \star *}$ & -0.016 & $0.208^{\star \star \star}$ & $-0.791^{\star \star \star}$ \\
\hline & $(0.082)$ & $(0.076)$ & $(0.088)$ & $(0.107)$ & $(0.057)$ & $(0.091)$ & $(0.076)$ & $(0.088)$ \\
\hline \multirow[t]{2}{*}{ Agglomerations } & 0.039 & 0.049 & 0.044 & 0.050 & 0.047 & 0.047 & 0.051 & 0.0522 \\
\hline & $(0.078)$ & $(0.078)$ & $(0.077)$ & $(0.077)$ & $(0.078)$ & $(0.077)$ & $(0.078)$ & $(0.079)$ \\
\hline \multirow[t]{2}{*}{ Urbanized regions } & -0.025 & -0.017 & -0.025 & -0.015 & -0.013 & -0.018 & -0.019 & -0.013 \\
\hline & $(0.080)$ & $(0.080)$ & $(0.080)$ & $(0.080)$ & $(0.080)$ & $(0.080)$ & $(0.081)$ & $(0.082)$ \\
\hline \multirow[t]{2}{*}{ Years of unemployment } & 0.015 & 0.008 & 0.011 & 0.010 & 0.012 & 0.010 & 0.010 & $0.029^{*}$ \\
\hline & $(0.015)$ & $(0.015)$ & $(0.015)$ & $(0.015)$ & $(0.015)$ & $(0.015)$ & $(0.015)$ & $(0.015)$ \\
\hline \multirow{2}{*}{$\begin{array}{l}\text { Either parent self-employed } \\
(\text { yes }=1, \text { no }=0)\end{array}$} & $0.369^{\star * *}$ & $0.374^{\star * *}$ & $0.378^{\star \star *}$ & $0.385^{\star * \star}$ & $0.384^{* * *}$ & $0.383^{* * *}$ & $0.378^{* * *}$ & $0.359^{\star * *}$ \\
\hline & $(0.070)$ & $(0.070)$ & $(0.070)$ & $(0.070)$ & $(0.070)$ & $(0.070)$ & $(0.070)$ & $(0.071)$ \\
\hline \multirow[t]{2}{*}{ Married $($ yes $=1$, no $=0)$} & 0.055 & 0.070 & 0.065 & 0.068 & 0.071 & 0.067 & 0.067 & 0.053 \\
\hline & $(0.055)$ & $(0.054)$ & $(0.054)$ & $(0.054)$ & $(0.054)$ & $(0.054)$ & $(0.054)$ & $(0.055)$ \\
\hline \multirow{2}{*}{$\begin{array}{l}\text { German nationality }(\text { yes }= \\
1, \text { no }=0)\end{array}$} & -0.114 & -0.082 & -0.083 & -0.071 & -0.079 & -0.076 & -0.072 & -0.079 \\
\hline & $(0.120)$ & $(0.120)$ & $(0.120)$ & $(0.120)$ & $(0.121)$ & $(0.120)$ & $(0.121)$ & $(0.125)$ \\
\hline \multirow[t]{2}{*}{ Age } & -0.003 & 0.0018 & 0.001 & 0.001 & 0.003 & 0.001 & 0.001 & 0.003 \\
\hline & $(0.015)$ & $(0.015)$ & $(0.015)$ & $(0.015)$ & $(0.015)$ & $(0.015)$ & $(0.015)$ & $(0.015)$ \\
\hline \multirow[t]{2}{*}{ Age, squared } & $0.0003^{*}$ & 0.0003 & $0.0003^{*}$ & $0.0003^{*}$ & 0.0002 & $0.0003^{*}$ & $0.0003^{*}$ & 0.0003 \\
\hline & $(0.000)$ & $(0.000)$ & $(0.000)$ & $(0.000)$ & $(0.000)$ & $(0.000)$ & $(0.000)$ & $(0.000)$ \\
\hline Years of education & $\begin{array}{l}0.079^{* * *} \\
(0.009)\end{array}$ & $\begin{array}{l}0.087^{* * *} \\
(0.009)\end{array}$ & $\begin{array}{l}0.078^{* * *} \\
(0.009)\end{array}$ & $\begin{array}{l}0.079^{* * *} \\
(0.009)\end{array}$ & $\begin{array}{l}0.076^{* * *} \\
(0.009)\end{array}$ & $\begin{array}{l}0.080^{* * *} \\
(0.009)\end{array}$ & $\begin{array}{l}0.087^{* * *} \\
(0.009)\end{array}$ & $\begin{array}{l}0.063^{* * *} \\
(0.009)\end{array}$ \\
\hline
\end{tabular}


Table 5 (continued)

Male $($ yes $=1$, no $=0$ )

\begin{tabular}{|c|c|c|c|c|c|c|c|}
\hline $\begin{array}{c}0.251^{* * *} \\
(0.053)\end{array}$ & $\begin{array}{c}0.327^{* * *} \\
(0.054)\end{array}$ & $\begin{array}{c}0.303^{* \star *} \\
(0.053)\end{array}$ & $\begin{array}{c}0.295^{\star * *} \\
(0.053)\end{array}$ & $\begin{array}{c}0.302^{\star * *} \\
(0.053)\end{array}$ & $\begin{array}{c}0.285^{\star * *} \\
(0.053)\end{array}$ & $\begin{array}{c}0.251^{* * *} \\
(0.055)\end{array}$ & $\begin{array}{c}0.268^{* * *} \\
(0.054)\end{array}$ \\
\hline $0.108^{\star \star \star}$ & $0.114^{* * *}$ & $0.110^{* * *}$ & $0.107^{* * *}$ & $0.108^{* * *}$ & $0.109^{* * *}$ & $0.110^{* * *}$ & $0.091^{* \star *}$ \\
\hline$(0.025)$ & $(0.025)$ & $(0.025)$ & $(0.025)$ & $(0.025)$ & $(0.025)$ & $(0.025)$ & $(0.025)$ \\
\hline 0.041 & 0.040 & 0.037 & 0.042 & 0.043 & 0.040 & 0.035 & 0.043 \\
\hline$(0.031)$ & $(0.031)$ & $(0.031)$ & $(0.031)$ & $(0.031)$ & $(0.031)$ & $(0.031)$ & $(0.031)$ \\
\hline $0.065^{\star \star \star}$ & $0.059^{* *}$ & $0.071^{* * *}$ & $0.069^{* \star *}$ & $0.066^{\star * *}$ & $0.069^{\star * *}$ & $0.069^{\star \star \star}$ & $0.075^{\star \star \star}$ \\
\hline$(0.024)$ & $(0.024)$ & $(0.024)$ & $(0.024)$ & $(0.024)$ & $(0.024)$ & $(0.024)$ & $(0.024)$ \\
\hline 0.001 & -0.003 & -0.003 & -0.004 & -0.0002 & -0.002 & -0.001 & -0.003 \\
\hline$(0.027)$ & $(0.027)$ & $(0.027)$ & $(0.027)$ & $(0.027)$ & $(0.027)$ & $(0.027)$ & $(0.027)$ \\
\hline-0.010 & -0.014 & -0.013 & -0.013 & -0.012 & -0.013 & -0.016 & -0.008 \\
\hline$(0.022)$ & $(0.022)$ & $(0.022)$ & $(0.022)$ & $(0.022)$ & $(0.022)$ & $(0.022)$ & $(0.022)$ \\
\hline $0.046^{\star \star \star}$ & $0.052^{\star \star \star}$ & $0.053^{* * *}$ & $0.052^{* * *}$ & $0.052^{* * *}$ & $0.052^{* * *}$ & $0.051^{* * *}$ & $0.053^{* \star *}$ \\
\hline$(0.012)$ & $(0.012)$ & $(0.012)$ & $(0.012)$ & $(0.012)$ & $(0.012)$ & $(0.012)$ & $(0.013)$ \\
\hline$-4.128^{* * *}$ & $-4.336^{* * *}$ & $-4.262^{\star \star *}$ & $-4.283^{\star * *}$ & $-4.332^{* \star *}$ & $-4.284^{\star * *}$ & $-4.360^{* * *}$ & $-3.968^{* * *}$ \\
\hline$(0.469)$ & $(0.469)$ & $(0.468)$ & $(0.468)$ & $(0.470)$ & $(0.470)$ & $(0.472)$ & $(0.481)$ \\
\hline 5,100 & 5,100 & 5,100 & 5,100 & 5,100 & 5,100 & 5,100 & 5,100 \\
\hline$-1,660$ & $-1,675$ & $-1,680$ & $-1,683$ & $-1,679$ & $-1,683$ & $-1,680$ & $-1,630$ \\
\hline $472.4^{\star \star *}$ & $431.9^{\star \star \star}$ & $418.2^{\star \star \star}$ & $422.9^{\star \star \star}$ & $419.6^{\star \star *}$ & $418.6^{\star * \star}$ & $418.5^{\star \star \star}$ & $434.4^{\star \star \star}$ \\
\hline 0.129 & 0.122 & 0.119 & 0.118 & 0.119 & 0.117 & 0.119 & 0.145 \\
\hline
\end{tabular}

Openness

Conscientiousness

Extraversion

Agreeableness

Neuroticism

Willingness to take risks

Intercept

Observations

Log-likelihood

Chi2

0.129

0.119

Notes: Results of a univariate probit regression. Dependent variable: Self-employment status (yes $=1, \mathrm{no}=0$ ). Robust standard errors in parentheses. ${ }^{* * *}$ :

statistically significant at the $1 \%$ level; **: statistically significant at the $5 \%$ level; *: statistically significant at the $10 \%$ level. 
Table 6: Probabilities of self-employment and choice of profession: Bivariate probit model

\begin{tabular}{|c|c|c|c|c|c|c|c|c|c|c|c|c|c|c|c|c|}
\hline & \multicolumn{2}{|c|}{1} & \multicolumn{2}{|c|}{ II } & \multicolumn{2}{|c|}{ III } & \multicolumn{2}{|c|}{ IV } & \multicolumn{2}{|c|}{ V } & \multicolumn{2}{|c|}{ VI } & \multicolumn{2}{|c|}{ VII } & \multicolumn{2}{|c|}{ VIII } \\
\hline & $\mathrm{k}=\mathrm{Ma}$ & nagers & $\begin{array}{r}\mathrm{k}=\mathrm{Phy} \\
\text { mathemat } \\
\text { engin } \\
\text { profes }\end{array}$ & $\begin{array}{l}\text { ysicists, } \\
\text { ticians, and } \\
\text { eeering } \\
\text { sionals }\end{array}$ & $\begin{array}{r}\mathrm{k}=\mathrm{H} \\
\text { profes }\end{array}$ & $\begin{array}{l}\text { Health } \\
\text { ssionals }\end{array}$ & $\begin{array}{l}\mathrm{k}=\mathrm{Te} \\
\text { profes }\end{array}$ & $\begin{array}{l}\text { aching } \\
\text { sionals }\end{array}$ & $\begin{array}{r}\mathrm{k}=\mathrm{C} \\
\text { profes }\end{array}$ & $\begin{array}{l}\text { Other } \\
\text { ssionals }\end{array}$ & $\mathrm{k}=$ Servic & ce workers & $\mathrm{k}=$ Trade & es workers & $\begin{array}{r}\mathrm{k}=\text { Elen } \\
\text { occup }\end{array}$ & $\begin{array}{l}\text { mentary } \\
\text { Jations }\end{array}$ \\
\hline Variables: & $\begin{array}{l}\text { Self-em- } \\
\text { ployment } \\
\text { choice }\end{array}$ & $\begin{array}{l}\text { Vocational } \\
\text { choice }\end{array}$ & $\begin{array}{l}\text { Self-em- } \\
\text { aloyment } \\
\text { choice }\end{array}$ & $\begin{array}{l}\text { Vocational } \\
\text { choice }\end{array}$ & $\begin{array}{l}\text { Self-em- } \\
\text { al ploymen } \\
\text { t choice }\end{array}$ & $\begin{array}{l}\text { Vocational } \\
\text { choice }\end{array}$ & $\begin{array}{l}\text { Self-em- } \\
\text { ployment } \\
\text { choice }\end{array}$ & $\begin{array}{l}\text { Vocational } \\
\text { choice }\end{array}$ & $\begin{array}{l}\text { Self-em- } \\
\text { I ployment } \\
\text { choice }\end{array}$ & $\begin{array}{l}\text { Vocational } \\
\text { choice }\end{array}$ & $\begin{array}{l}\text { Self-em- } \\
\text { ployment } \\
\text { choice }\end{array}$ & $\begin{array}{l}\text { Vocational } \\
\text { choice }\end{array}$ & $\begin{array}{l}\text { Self-em- } \\
\text { ployment } \\
\text { choice }\end{array}$ & $\begin{array}{l}\text { Vocational } \\
\text { choice }\end{array}$ & $\begin{array}{l}\text { Self-em- } \\
\text { ployment } \\
\text { choice }\end{array}$ & $\begin{array}{l}\text { Vocational } \\
\text { choice }\end{array}$ \\
\hline $\begin{array}{l}\text { Predicted } \\
\text { probability of } \\
\text { having profession } k\end{array}$ & $\begin{array}{l}-0.0832 \\
(0.227)\end{array}$ & - & $\begin{array}{c}0.790^{\star * *} \\
(0.294)\end{array}$ & - & $\begin{array}{c}0.550 \\
(1.633)\end{array}$ & - & $\begin{array}{c}0.612 \\
(0.450)\end{array}$ & - & $\begin{array}{l}1.031^{* * *} \\
(0.238)\end{array}$ & - & $\begin{array}{l}1.044^{* *} \\
(0.473)\end{array}$ & - & $\begin{array}{l}-0.171 \\
(0.516)\end{array}$ & - & $\begin{array}{c}-2.007^{\star * *} \\
(0.083)\end{array}$ & - \\
\hline $\begin{array}{l}\text { Father had } \\
\text { profession } k\end{array}$ & 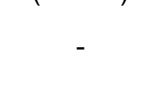 & $\begin{array}{l}0.333^{\star * *} \\
(0.081)\end{array}$ & 1 & $\begin{array}{l}0.364^{* * *} \\
(0.066)\end{array}$ & $1,0=0$ & $\begin{array}{c}0.830^{* * *} \\
(0.156)\end{array}$ & $10=0$ & $\begin{array}{l}0.572 * * * \\
(0.142)\end{array}$ & $10=0$ & $\begin{array}{l}0.432^{* * *} \\
(0.056)\end{array}$ & $10=-1$ & $\begin{array}{c}0.218 \\
(0.152)\end{array}$ & $10=-1$ & $\begin{array}{l}0.371^{* \star *} \\
(0.050)\end{array}$ & - & $\begin{array}{l}0.207^{\star * *} \\
(0.039)\end{array}$ \\
\hline $\begin{array}{l}\text { Either parent self- } \\
\text { employed (yes = } 1 \text {, } \\
\text { no }=0 \text { ) }\end{array}$ & $\begin{array}{l}0.387^{\star \star \star} \\
(0.070)\end{array}$ & $\begin{array}{c}0.129 \\
(0.084)\end{array}$ & $\begin{array}{c}0.364^{\star \star *} \\
(0.069)\end{array}$ & $\begin{array}{l}-0.0300 \\
(0.078)\end{array}$ & $\begin{array}{c}0.368^{\star * *} \\
(0.087)\end{array}$ & $\begin{array}{l}0.0889 \\
(0.089)\end{array}$ & $\begin{array}{c}0.384^{\star * *} \\
(0.070)\end{array}$ & $\begin{array}{r}-0.0205 \\
(0.103)\end{array}$ & $\begin{array}{c}0.333^{\star * *} \\
(0.072)\end{array}$ & $\begin{array}{l}0.0881 \\
(0.065)\end{array}$ & $\begin{array}{c}0.371^{\star \star *} \\
(0.069)\end{array}$ & $\begin{array}{l}0.0176 \\
(0.081)\end{array}$ & $\begin{array}{c}0.372^{\star \star *} \\
(0.071)\end{array}$ & $\begin{array}{l}-0.0655 \\
(0.083)\end{array}$ & $\begin{array}{l}0.114^{\star} \\
(0.067)\end{array}$ & $\begin{array}{c}-0.257^{* * *} \\
(0.069)\end{array}$ \\
\hline $\begin{array}{l}\text { Male }(\text { yes }=1, \text { no }= \\
0)\end{array}$ & $\begin{array}{c}0.288^{* * *} \\
(0.054)\end{array}$ & $\begin{array}{l}0.420^{\star * *} \\
(0.062)\end{array}$ & $\begin{array}{l}0.220^{\star \star \star} \\
(0.056)\end{array}$ & $\begin{array}{l}0.681^{* * *} \\
(0.055)\end{array}$ & $\begin{array}{c}0.322^{\star \star \star} \\
(0.096)\end{array}$ & $\begin{array}{l}-0.549^{\star * *} \\
(0.061)\end{array}$ & $\begin{array}{c}0.316^{\star * *} \\
(0.055)\end{array}$ & $\begin{array}{c}-0.526^{\star \star \star} \\
(0.070)\end{array}$ & $\begin{array}{c}0.358^{* * *} \\
(0.052)\end{array}$ & $\begin{array}{c}-0.332^{\star \star \star} \\
(0.043)\end{array}$ & $\begin{array}{c}0.371^{\star * *} \\
(0.056)\end{array}$ & $\begin{array}{c}-0.764^{* \star *} \\
(0.055)\end{array}$ & $\begin{array}{c}0.328^{\star * *} \\
(0.125)\end{array}$ & $\begin{array}{l}1.145^{\star \star *} \\
(0.064)\end{array}$ & $\begin{array}{c}0.130^{\star * \star} \\
(0.047)\end{array}$ & $\begin{array}{l}-0.095^{\star *} \\
(0.041)\end{array}$ \\
\hline Openness & $\begin{array}{l}0.116^{\star * *} \\
(0.025)\end{array}$ & $\begin{array}{l}0.090^{\star * *} \\
(0.0255)\end{array}$ & $\begin{array}{l}0.091^{* * *} \\
(0.024)\end{array}$ & $\begin{array}{l}0.116^{* * *} \\
(0.023)\end{array}$ & $\begin{array}{c}0.108^{* * *} \\
(0.029)\end{array}$ & $\begin{array}{l}0.066^{\star *} \\
(0.028)\end{array}$ & $\begin{array}{l}0.099^{* * *} \\
(0.0256)\end{array}$ & $\begin{array}{l}0.208^{\star * *} \\
(0.0308)\end{array}$ & $\begin{array}{l}0.089^{\star \star *} \\
(0.0239)\end{array}$ & $\begin{array}{l}0.061^{* * *} \\
(0.0185)\end{array}$ & $\begin{array}{c}0.114^{\star * *} \\
(0.024)\end{array}$ & $\begin{array}{c}-0.080^{\star * *} \\
(0.022)\end{array}$ & $\begin{array}{c}0.101^{* \star *} \\
(0.028)\end{array}$ & $\begin{array}{c}-0.085^{* * *} \\
(0.024)\end{array}$ & $\begin{array}{c}-0.032 \\
(0.024)\end{array}$ & $\begin{array}{c}-0.161^{* * *} \\
(0.018)\end{array}$ \\
\hline Conscientiousness & $\begin{array}{c}0.042 \\
(0.031)\end{array}$ & $\begin{array}{c}0.017 \\
(0.032)\end{array}$ & $\begin{array}{c}0.049 \\
(0.030)\end{array}$ & $\begin{array}{l}-0.052^{*} \\
(0.028)\end{array}$ & $\begin{array}{c}0.035 \\
(0.033)\end{array}$ & $\begin{array}{c}0.055^{\star} \\
(0.033)\end{array}$ & $\begin{array}{c}0.046 \\
(0.031)\end{array}$ & $\begin{array}{c}-0.123^{* * *} \\
(0.040)\end{array}$ & $\begin{array}{c}0.053^{*} \\
(0.0300)\end{array}$ & $\begin{array}{c}-0.062^{* * *} \\
(0.023)\end{array}$ & $\begin{array}{c}0.040 \\
(0.0303)\end{array}$ & $\begin{array}{l}-0.007 \\
(0.031)\end{array}$ & $\begin{array}{c}0.046 \\
(0.034)\end{array}$ & $\begin{array}{c}0.128^{* * *} \\
(0.030)\end{array}$ & $\begin{array}{c}0.043^{\star} \\
(0.025)\end{array}$ & $\begin{array}{c}0.024 \\
(0.023)\end{array}$ \\
\hline Extraversion & $\begin{array}{c}0.066^{\star \star \star} \\
(0.024)\end{array}$ & $\begin{array}{c}0.012 \\
(0.026)\end{array}$ & $\begin{array}{c}0.081^{* * *} \\
(0.023)\end{array}$ & $\begin{array}{c}-0.152^{\star \star *} \\
(0.022)\end{array}$ & $\begin{array}{c}0.075^{\star \star \star} \\
(0.028)\end{array}$ & $\begin{array}{c}-0.096^{\star * *} \\
(0.027)\end{array}$ & $\begin{array}{c}0.069^{* \star *} \\
(0.024)\end{array}$ & $\begin{array}{l}-0.015 \\
(0.029)\end{array}$ & $\begin{array}{l}0.056^{\star \star} \\
(0.023)\end{array}$ & $\begin{array}{c}0.032 \\
(0.019)\end{array}$ & $\begin{array}{l}0.060^{* *} \\
(0.023)\end{array}$ & $\begin{array}{c}0.074^{\star \star *} \\
(0.024)\end{array}$ & $\begin{array}{c}0.070^{\star * *} \\
(0.024)\end{array}$ & $\begin{array}{c}0.019 \\
(0.023)\end{array}$ & $\begin{array}{l}0.080^{* * *} \\
(0.0193)\end{array}$ & $\begin{array}{c}0.050^{\star * *} \\
(0.018)\end{array}$ \\
\hline Agreeableness & $\begin{array}{l}-0.004 \\
(0.027)\end{array}$ & $\begin{array}{l}-0.049^{*} \\
(0.029)\end{array}$ & $\begin{array}{l}-0.001 \\
(0.026)\end{array}$ & $\begin{array}{l}-0.025 \\
(0.025)\end{array}$ & $\begin{array}{c}-0.004 \\
(0.028)\end{array}$ & $\begin{array}{c}0.037 \\
(0.029)\end{array}$ & $\begin{array}{l}-0.008 \\
(0.027)\end{array}$ & $\begin{array}{l}0.116^{* * *} \\
(0.036)\end{array}$ & $\begin{array}{c}0.002 \\
(0.026)\end{array}$ & $\begin{array}{l}-0.015 \\
(0.022)\end{array}$ & $\begin{array}{l}-0.007 \\
(0.026)\end{array}$ & $\begin{array}{l}0.051^{*} \\
(0.028)\end{array}$ & $\begin{array}{c}-0.003 \\
(0.027)\end{array}$ & $\begin{array}{c}-0.018 \\
(0.026)\end{array}$ & $\begin{array}{c}-0.0138 \\
(0.022)\end{array}$ & $\begin{array}{c}-0.011 \\
(0.021)\end{array}$ \\
\hline Neuroticism & $\begin{array}{l}-0.017 \\
(0.022)\end{array}$ & $\begin{array}{c}-0.075^{\star \star *} \\
(0.024)\end{array}$ & $\begin{array}{l}-0.008 \\
(0.021)\end{array}$ & $\begin{array}{l}-0.035^{*} \\
(0.021)\end{array}$ & $\begin{array}{l}-0.011 \\
(0.023)\end{array}$ & $\begin{array}{l}-0.041^{*} \\
(0.024)\end{array}$ & $\begin{array}{l}-0.012 \\
(0.022)\end{array}$ & $\begin{array}{l}-0.021 \\
(0.028)\end{array}$ & $\begin{array}{l}-0.003 \\
(0.021)\end{array}$ & $\begin{array}{c}-0.043^{* *} \\
(0.017)\end{array}$ & $\begin{array}{l}-0.016 \\
(0.021)\end{array}$ & $\begin{array}{c}0.012 \\
(0.022)\end{array}$ & $\begin{array}{l}-0.009 \\
(0.024)\end{array}$ & $\begin{array}{c}0.079^{* * *} \\
(0.022)\end{array}$ & $\begin{array}{c}0.025 \\
(0.018)\end{array}$ & $\begin{array}{c}0.063^{* * \star} \\
(0.017)\end{array}$ \\
\hline
\end{tabular}


Table 6 (continued)

\begin{tabular}{|c|c|c|c|c|c|c|c|c|c|c|c|c|c|c|c|c|}
\hline $\begin{array}{l}\text { Willingness to take } \\
\text { risks }\end{array}$ & $\begin{array}{l}0.051^{* * *} \\
(0.012)\end{array}$ & $\begin{array}{l}0.048^{* * *} \\
(0.014)\end{array}$ & $\begin{array}{c}0.052^{* * *} \\
(0.012)\end{array}$ & $\begin{array}{l}-0.009 \\
(0.0118)\end{array}$ & $\begin{array}{c}0.053^{\star * *} \\
(0.013)\end{array}$ & $\begin{array}{l}-0.021 \\
(0.014)\end{array}$ & $\begin{array}{l}0.054^{\star \star *} \\
(0.012)\end{array}$ & $\begin{array}{l}-0.040^{\star *} \\
(0.016)\end{array}$ & $\begin{array}{c}0.051^{* * *} \\
(0.012)\end{array}$ & $\begin{array}{l}-0.008 \\
(0.010)\end{array}$ & $\begin{array}{c}0.051^{\star * *} \\
(0.012)\end{array}$ & $\begin{array}{l}-0.008 \\
(0.013)\end{array}$ & $\begin{array}{c}0.053^{\star * \star} \\
(0.013)\end{array}$ & $\begin{array}{l}0.031^{\star *} \\
(0.012)\end{array}$ & $\begin{array}{c}0.037^{* * *} \\
(0.011)\end{array}$ & $\begin{array}{l}-0.001 \\
(0.010)\end{array}$ \\
\hline Agglomerations & $\begin{array}{c}0.038 \\
(0.076)\end{array}$ & - & $\begin{array}{c}0.042 \\
(0.074)\end{array}$ & - & $\begin{array}{c}0.044 \\
(0.077)\end{array}$ & - & $\begin{array}{c}0.048 \\
(0.077)\end{array}$ & - & $\begin{array}{c}0.037 \\
(0.074)\end{array}$ & - & $\begin{array}{c}0.048 \\
(0.075)\end{array}$ & - & $\begin{array}{c}0.051 \\
(0.077)\end{array}$ & - & $\begin{array}{c}0.031 \\
(0.053)\end{array}$ & - \\
\hline Urbanized regions & $\begin{array}{l}-0.022 \\
(0.079)\end{array}$ & - & $\begin{array}{l}-0.018 \\
(0.077)\end{array}$ & - & $\begin{array}{l}-0.024 \\
(0.080)\end{array}$ & - & $\begin{array}{l}-0.017 \\
(0.079)\end{array}$ & - & $\begin{array}{l}-0.016 \\
(0.076)\end{array}$ & - & $\begin{array}{l}-0.019 \\
(0.078)\end{array}$ & - & $\begin{array}{l}-0.016 \\
(0.079)\end{array}$ & - & $\begin{array}{l}-0.014 \\
(0.054)\end{array}$ & - \\
\hline Years of education & $\begin{array}{l}0.077^{\star * *} \\
(0.009)\end{array}$ & - & $\begin{array}{l}0.081^{* * *} \\
(0.009)\end{array}$ & - & $\begin{array}{c}0.078^{\star \star \star} \\
(0.010)\end{array}$ & - & $\begin{array}{l}0.079^{* * *} \\
(0.009)\end{array}$ & - & $\begin{array}{l}0.071^{\star * *} \\
(0.009)\end{array}$ & - & $\begin{array}{c}0.079^{* * *} \\
(0.009)\end{array}$ & - & $\begin{array}{c}0.085^{\star \star *} \\
(0.010)\end{array}$ & - & $\begin{array}{c}0.043^{\star * *} \\
(0.007)\end{array}$ & - \\
\hline $\begin{array}{l}\text { Years of } \\
\text { unemployment }\end{array}$ & $\begin{array}{l}0.015 \\
(0.014)\end{array}$ & - & $\begin{array}{c}0.008 \\
(0.014)\end{array}$ & - & $\begin{array}{c}0.011 \\
(0.015)\end{array}$ & - & $\begin{array}{c}0.011 \\
(0.0145)\end{array}$ & - & $\begin{array}{l}0.011 \\
(0.014)\end{array}$ & - & $\begin{array}{c}0.011 \\
(0.014)\end{array}$ & - & $\begin{array}{c}0.009 \\
(0.015)\end{array}$ & - & $\begin{array}{l}0.023^{* *} \\
(0.011)\end{array}$ & - \\
\hline $\begin{array}{l}\text { Married (yes }=1, \text { no }= \\
0 \text { ) }\end{array}$ & $\begin{array}{c}0.054 \\
(0.054)\end{array}$ & - & $\begin{array}{c}0.064 \\
(0.052)\end{array}$ & - & $\begin{array}{c}0.066 \\
(0.054)\end{array}$ & - & $\begin{array}{c}0.0676 \\
(0.0540)\end{array}$ & - & $\begin{array}{c}0.066 \\
(0.051)\end{array}$ & - & $\begin{array}{c}0.068 \\
(0.053)\end{array}$ & - & $\begin{array}{c}0.067 \\
(0.054)\end{array}$ & - & $\begin{array}{c}0.044 \\
(0.037)\end{array}$ & - \\
\hline $\begin{array}{l}\text { German }(\text { yes }=1, \text { no }= \\
0)\end{array}$ & $\begin{array}{l}-0.111 \\
(0.119)\end{array}$ & - & $\begin{array}{l}-0.067 \\
(0.115)\end{array}$ & - & $\begin{array}{l}-0.082 \\
(0.120)\end{array}$ & - & $\begin{array}{l}-0.0748 \\
(0.119)\end{array}$ & - & $\begin{array}{l}-0.081 \\
(0.115)\end{array}$ & - & $\begin{array}{l}-0.083 \\
(0.117)\end{array}$ & - & $\begin{array}{l}-0.067 \\
(0.121)\end{array}$ & - & $\begin{array}{l}-0.068 \\
(0.084)\end{array}$ & - \\
\hline Age & $\begin{array}{l}-0.003 \\
(0.015)\end{array}$ & - & $\begin{array}{c}0.003 \\
(0.014)\end{array}$ & - & $\begin{array}{c}0.001 \\
(0.015)\end{array}$ & - & $\begin{array}{l}0.0004 \\
(0.015)\end{array}$ & - & $\begin{array}{c}0.003 \\
(0.014)\end{array}$ & - & $\begin{array}{l}0.0004 \\
(0.015)\end{array}$ & - & $\begin{array}{c}0.001 \\
(0.015)\end{array}$ & - & $\begin{array}{l}-0.001 \\
(0.010)\end{array}$ & - \\
\hline Age, squared & $\begin{array}{l}0.0003^{*} \\
(0.000)\end{array}$ & - & $\begin{array}{l}0.0002 \\
(0.000)\end{array}$ & - & $\begin{array}{l}0.0003 \\
(0.000)\end{array}$ & - & $\begin{array}{l}0.0003^{*} \\
(0.000)\end{array}$ & - & $\begin{array}{l}0.0002 \\
(0.000)\end{array}$ & - & $\begin{array}{l}0.0003^{*} \\
(0.000)\end{array}$ & - & $\begin{array}{l}0.0003^{*} \\
(0.000)\end{array}$ & - & $\begin{array}{l}0.0002^{*} \\
(0.000)\end{array}$ & - \\
\hline Intercept & $\begin{array}{l}-4.08^{\star \star \star} \\
(0.468)\end{array}$ & $\begin{array}{l}-2.028^{\star \star \star} \\
(0.295)\end{array}$ & $\begin{array}{c}-4.374^{\star \star \star} \\
(0.452)\end{array}$ & $\begin{array}{l}-0.832^{* \star *} \\
(0.247)\end{array}$ & $\begin{array}{l}-4.280^{* \star *} \\
(0.469)\end{array}$ & $\begin{array}{l}-1.430^{\star * *} \\
(0.295)\end{array}$ & $\begin{array}{l}-4.26^{\star \star \star} \\
(0.468)\end{array}$ & $\begin{array}{l}-2.034^{* * *} \\
(0.333)\end{array}$ & $\begin{array}{l}-4.338^{* \star *} \\
(0.453)\end{array}$ & $\begin{array}{l}-0.470^{* *} \\
(0.208)\end{array}$ & $\begin{array}{l}-4.272^{* \star *} \\
(0.463)\end{array}$ & $\begin{array}{l}-1.189^{\star \star *} \\
(0.265)\end{array}$ & $\begin{array}{c}-4.380^{\star \star \star *} \\
(0.469)\end{array}$ & $\begin{array}{l}-2.865^{* * *} \\
(0.274)\end{array}$ & $\begin{array}{l}-2.19^{\star \star \star} \\
(0.418)\end{array}$ & $\begin{array}{c}-0.550^{\star * \star} \\
(0.206)\end{array}$ \\
\hline Observations & 5,100 & 5,100 & 5,100 & 5,100 & 5,100 & 5,100 & 5,100 & 5,100 & 5,100 & 5,100 & 5,100 & 5,100 & 5,100 & 5,100 & 5,100 & 5,100 \\
\hline Rho & 0.311 & 0.311 & -0.560 & -0.560 & -0.161 & -0.161 & -0.230 & -0.230 & -0.488 & -0.488 & -0.506 & -0.506 & 0.217 & 0.217 & 0.908 & 0.908 \\
\hline $\begin{array}{l}\text { Wald test of rho=0: } \\
\text { Wald chi2 }\end{array}$ & $6.854^{* * *}$ & & $11.33^{\star \star \star}$ & & 0.041 & & 1.323 & & $10.85^{\star * *}$ & & $4.315^{\star \star}$ & & 0.500 & & $32.94^{\star * *}$ & \\
\hline
\end{tabular}

Notes: Robust standard errors in parentheses. ${ }^{* *}$ : statistically significant at the $1 \%$ level; **: statistically significant at the $5 \%$ level; *: statistically significant at the $10 \%$ level. 
probability of self-employment. This result indicates that those persons who are more likely to be managers due to their personal characteristics are not more likely to become self-employed. The significant and positive coefficient gained in the univariate probit regression mainly highlights the importance of a managerial occupational environment for self-employment, for instance, through developing the entrepreneurial skills necessary for managing an own business. However, this positive effect is less likely due to an aboveaverage proclivity of "managerial" types for entrepreneurship; rather, "managerial" types are on average equally likely to choose selfemployment or dependent employment.

There are two effects that do not change sign, but do become stronger in the bivariate probit setting as compared to the univariate model. One of these effects concerns the group of other professionals, which includes business professionals, legal professionals, social sciences professionals, and artists. The personal characteristics of people who are more likely to be in one of these professions imply a relatively high propensity for being self-employed. This result may also indicate that pro-entrepreneurial types are more likely to find one of these professions attractive. This finding is in line with a previous study on entrepreneurial personality and vocational choice by Sorgner (2012), who shows that people with a pronounced entrepreneurial personality are more likely to choose enterprising (e.g., manager, lawyer) and artistic (musician, filmmaker) professions. Another effect that becomes stronger but does not change its negative sign is for persons in elementary occupations, who appear to be generally less entrepreneurial.

An interesting result is obtained with regard to physical, mathematical, and engineering professionals. According to the univariate model, being in these professions had a significantly negative effect on the propensity for self-employment; however, the results of the bivariate probit model indicate that people who choose one of these 
professional environments are more likely to be self-employed. This result indicates that while these occupational environments appear to attract people with pronounced entrepreneurial attitudes, they are less conducive to the actual exercise of self-employment. The results for the service workers should be interpreted cautiously since this was the only group of professions for which our instrument variable does not have a significant effect. The positive effect of being a service worker on the probability of self-employment may indicate, for instance, that a rather small minimum efficient size and low requirements with regard to human and financial capital make entrepreneurial entry relatively easy in this type of profession. However, based on our results we cannot exclude the possibility that this effect is partly due to self-selection of more entrepreneurial people into these professions.

Finally, as mentioned above, the results for health professionals, teaching professionals, and craftspeople should be interpreted based on the findings from the univariate probit regression, since selfemployment choice and the choice of one of these professions are less likely to be interrelated. Therefore, we conclude (based on the results from Table 5) that life science and health professionals, along with trades workers, are more likely to become self-employed due to an occupational environment that is conducive to entrepreneurship, rather than due to entrepreneurial attitudes. Indeed, self-employment in both these professional environments is highly regulated, meaning that entrepreneurial opportunities in these occupations are highly standardized and easy to pursue for those having the necessary human capital.

Our study also sheds some light on the determinants of vocational choice. Father's occupation seems to have a strong effect on his child's vocational choice in almost all occupations, but other personal characteristics are worth mention, too. In line with previous literature, we find a significant relationship between personality traits and vocational choice (Holland, 1985; Filer, 1986; Sorgner, 2012). 
Interestingly, openness to experience-a personality dimension that is often related to creativity and entrepreneurship_appears to be negatively associated with the probability of being a service worker or working in an elementary occupation. This might be why these occupational groups demonstrate the lowest self-employment rates (see Figure 2). Interestingly, people with a high willingness to take risks-an attribute of many entrepreneurs (Caliendo, Fossen, and Kritikos 2009) - are significantly less likely to be teachers, which can be regarded as a relatively secure profession in terms of earning risk and the risk of unemployment.

\section{Conclusions}

We have argued that self-employment is a dynamic process that occurs in several steps. Specifically, we identified vocational choice as a first step toward the decision to become self-employed. The choice of profession occurs relatively early in life and tends to have a pronounced effect on the career path, identity, and the accumulations of occupationspecific human capital. Hence, to a certain degree, self-employment may be occupation-specific in that certain occupations provide an environment that is more conducive to self-employment than others. We show that a person's profession makes a considerable contribution to explaining the decision to be self-employed. At least two reasons can be identified for such an effect. First, people with pronounced entrepreneurial attitudes may choose an occupation that complements their values and matches their needs, which is then the reason for observing relatively high self-employment rates in occupations such as business professionals, legal professionals, and artists. In this case, occupation-specific self-employment rates mainly result from the high entrepreneurial potential of those choosing these occupations. Second, certain occupational environments might be conducive to fostering selfemployment even among those who originally did not intend to found an own business. In this case, working in a certain occupation might 
stimulate the development of entrepreneurial skills (e.g., in managerial occupations), or the occupation may be characterized by a high share of standardized entrepreneurial role models or entry regulations that make self-employment particularly attractive (e.g., for health professionals, craftsmen). Hence, both the choice of a profession and entrepreneurial choice appear to be highly interrelated and constitute an important part of a person's career development.

Our findings contribute to the literature on entrepreneurial choice in several respects. First, we demonstrate the importance of vocational choice and of occupation-specific environment in the decision to be selfemployed. Second, we enrich the discussion by showing that personality plays an important role in the development of an entrepreneurial career, probably most acutely early in the life course when vocational choices are being made. The choice of a certain profession, in turn, may be regarded as an important step either toward or away from self-employment. Third, we present an empirical model that allows analyzing the two related choices and identifying the main links between them. Specifically, our empirical setting utilizes a bivariate probit model that provides consistent estimates of the model of entrepreneurial choice accounting for its interdependence with the choice of a profession.

Having shown a strongly significant effect of the choice of a certain profession on self-employment, the question remains as to what makes a certain professional environment more conducive to entrepreneurship than others. These may include such things as minimum efficient size, entry regulation, occupation-specific labor market conditions, and entrepreneurial career models, among others. Analysis of these conditions is a promising avenue for future research. After having discovered the elements that make an occupational environment conducive to entrepreneurship, the next topic of investigation would be how certain occupations can become more entrepreneurially conducive and how to achieve a good match between entrepreneurial individuals 
and occupations that foster their entrepreneurial talent. Since entrepreneurial choices are likely to develop out of previous career choices, including choice of profession, entrepreneurial careers can be at least partly predicted, and thus efficiently guided, early in the life course. Hence, a better match between people who show early talent or interest in entrepreneurship and vocations that are conducive to entrepreneurship or at the very least not impede the development of an individual's entrepreneurial capacities may be addressed in the course of early career counseling of young people.

The findings of this study also contribute to the literature on vocational choice. Specifically, we show that occupation following is still a pronounced phenomenon in Germany, albeit one with a great deal of variation across occupations. Occupation following is particularly strong in trade occupations (about 47 percent) and it is almost absent in service occupations (about 3.6 percent). This finding points to the role of intergenerational transmission of skills, attitudes, and preferences in vocational choice. Furthermore, we found support for the literature on the role personality traits play in vocational choice (Holland, 1985).

Overall, we conclude that entrepreneurial choice evolves from an individual's personality, attitudes, previous career choices, and experiences in a given context (Obschonka and Silbereisen, 2012). Thus, an integrated approach that studies entrepreneurship from a lifespan perspective and accounts for the role of different contexts and their interplay appears to be a promising one. 


\section{References}

Bauernschuster, Stefan, Oliver Falck, and Stephan Heblich (2009): Training and Innovation. Journal of Human Capital, 3, 323-353.

Borghans, Lex, Angela Lee Duckworth, James J. Heckman, and Bas ter Weel (2008): The Economics and Psychology of Personality Traits. Journal of Human Resources, 4, 972-1059.

Bosma, Niels, Jolanda Hessels, Veronique Schutjens, Mirjam Van Praag, Ingrid Verheul (2012): Entrepreneurship and Role Models. Journal of Economic Psychology, 33, 410-424.

Caliendo, Marco, Frank M. Fossen, and Alexander Kritikos (2009): Risk Attitudes of Nascent Entrepreneurs-New Evidence from an Experimentally Validated Survey. Small Business Economics, 32, 153-167.

Costa, Paul T. Jr. and Robert R. McCrae (1992): Revised NEO Personality Inventory (NEO-PI-R) and NEO Five Factor Inventory (NEO-FFI) Professional Manual. Odessa, FL: PAR.

Dohmen, Thomas, Armin Falk, David Huffman, Uwe Sunde, Jürgen Schupp, and Gert G. Wagner (2011): Individual Risk Attitudes: Measurement, Determinants, and Behavioral Consequences. Journal of the European Economic Association, 9, 522-550.

Dunn, Thomas and Douglas Holtz-Eakin (2000): Financial Capital, Human Capital, and the Transition to Self-Employment: Evidence from Intergenerational Links. Journal of Labor Economics, 18(2), 282-305.

Fabbri, Daniele and Chiara Monfardini (2008): Style of practice and assortative mating: a recursive probit analysis of Caesarean section scheduling in Italy. Applied Economics, 40, 1411-1423.

Filer, Randall K. (1986): The Role of Personality and Tastes in Determining Occupational Structure. Industrial and Labor Relations Review, 39, 412-424.

Fritsch, Michael, Elisabeth Bublitz, and Alina Rusakova (2012): Berufstätigkeit und Entrepreneurial Choice - Welchen Einfluss hat die Berufstätigkeit auf die Entscheidung zur unternehmerischen Selbständigkeit? In Christoph Köhler and Alexandra Krause (eds.): Arbeit als Ware? Zur Theorie flexibler Arbeitsmärkte, Bielefeld: transcript.

Fritsch, Michael, Alexander Kritikos and Alina Rusakova (2012): Who Starts A Business and Who Is Self-employed in Germany? IZA Discussion Paper, \#6326, 2012.

Gathmann, Cristina and Uta Schönberg (2010): How General is Human Capital? A Task-Based Approach. Journal of Labor Economics, 28, 1-49. 
Gerlitz, Jean-Yves and Jürgen Schupp (2005): Zur Erhebung der Big-Fivebasierten Persönlichkeitsmerkmale im SOEP, Research Notes.

Berlin: German Institute for Economic Research (DIW).

Greene, William (1998): Gender Economics Courses in Liberal Arts Colleges: Further Results. The Journal of Economic Education, 29, 291-300.

Greene, William (2008): Econometric Analysis. 6th edition, Upper Saddle River: Pearson Prentice Hall.

Holland, John L. (1985): Making Vocational Choices: A Theory of Careers. Englewood Cliffs, NJ: Prentice-Hall.

International Labour Office (1990): ISCO-88, International Standard Classificaton of Occupations. Geneva: International Labor Office.

Jonsson, Jan O., David B. Grusky, Matthew Di Carlo, Reinhard Pollak, and Mary C. Brinton (2009): Microclass Mobility: Social Reproduction in Four Countries. American Journal of Sociology, 114, 977-1036.

Karlsson, Tobias and Maria Stanfors (2011): In the footsteps of their fathers? Occupational following among Swedish tobacco workers. Continuity and Change, 26, 45-68. doi:10.1017/S0268416010000330

Kassouf, Ana Lucia and Rodolfo Hoffmann (2006): Work-Related Injuries Involving Children and Adolescents: Application of a Recursive Bivariate Probit Model. Brazilian Review of Econometrics, 26, 105126.

Katz, Jerome A. (1992): A Psychosocial Cognitive Model of Employment Status Choice. Entrepreneurship: Theory and Practice, 17, 29-37.

Kihlstrom, Richard E. and Jean-Jacques Laffont (1979): A General Equilibrium Entrepreneurial Theory of Firm Formation Based on Risk Aversion. Journal of Political Economy, 87, 719-748.

Knight, Frank. H. (1921): Risk, Uncertainty and Profit. New York: Houghton Mifflin.

Laband, David N. and Bernard F. Lentz (1983): Like Father, Like Son: Toward an Economic Theory of Occupational Following. Southern Economic Journal, 50, 474-493.

Laband, David N. and Bernard F. Lentz (1989): Why so Many Children of Doctors Become Doctors: Nepotism versus Human Capital Transfers, Journal of Human Resources, 24, 396-413.

Lazear, Edward P. (2004): Balanced Skills and Entrepreneurship. American Economic Review, 94, 208-211.

Lazear, Edward P. (2005): Entrepreneurship. Journal of Labor Economics, 23, 649-680.

Lucas, Robert E., Jr. (1978): On the Size Distribution of Business Firms. Bell Journal of Economics, 9, 508-523.

Nanda, Ramana and Jesper B. Sørensen (2010): Workplace peers and entrepreneurship. Management Science, 56, 1116-1126. 
Nedelkoska, Ljubica and Frank Neffke (2010): Human Capital Mismatches along the Career Path, Jena Economic Research Papers 051-2010, Friedrich Schiller University and Max Planck Institute of Economics Jena.

Obschonka, Martin, Rainer K. Silbereisen and Eva Schmitt-Rodermund (2010): Entrepreneurial Intention as Developmental Outcome. Journal of Vocational Behavior, 77, 63-72.

Obschonka, Martin, Rainer K. Silbereisen (2012): Entrepreneurship from a developmental science perspective. International Journal of Developmental Science, 6, 107-115.

Parker, Simon C. (2009): The Economics of Entrepreneurship. Cambridge: Cambridge University Press.

Rauch, Andreas and Michael Frese (2007): Let's Put the Person Back into Entrepreneurship Research: A Meta-Analysis on the Relationship Between Business Owners' Personality Traits, Business Creation, and Success. European Journal of Work and Organizational Psychology, 16, 353-385.

Rhine, Sherrie L.W., William H. Greene and Maude Toussaint-Comeau (2006): The Importance of Check-Cashing Businesses to the Unbanked: Racial/Ethnic Differences, The Review of Economics and Statistics, 88, 146-157.

Schmitt-Rodermund,Eva (2004): Pathways to Successful Entrepreneurship: Personality, Parenting, Entrepreneurial Competence, and Interests. Journal of Vocational Behavior, 65, 498518.

Schmitt-Rodermund, Eva (2007): The Long Way to Entrepreneurship.

Personality, Parenting, Early Interests and Competencies for Entrepreneurial Activity Among the Termites. In Rainer K. Silbereisen and Richard M. Lerner (eds.): Approaches to Positive Youth Development, Thousand Oaks: Sage, 205-224..

Schneider, Benjamin (1987): The People Make the Place. Personnel Psychology, 40, 437-453.

Sorgner, Alina (2012): A Physician With a Soul of a Cook? Entrepreneurial Personality Across Occupations. Jena Economic Research Papers 063 - 2012, Friedrich Schiller University and Max Planck Institute for Economics, Jena.

Sorgner, Alina and Michael Fritsch (2013): Occupational Choice and SelfEmployment-Are They Related? Jena Economic Research Papers 001-2013, Friedrich Schiller University and Max Planck Institute for Economics, Jena.

Wagner, Gerd G., Joachim R. Frick, and Jürgen Schupp (2007): The German Socio-Economic Panel Study (SOEP): Scope, evolution and enhancements. Journal of Applied Social Science Studies, 127, 139169. 
Zhang, Zhen and Richard D. Arvey (2009): Rule breaking in adolescence and entrepreneurial status: An empirical investigation, Journal of Business Venturing, 24, 436-447.

Zhao, Hao and Scott E. Seibert (2006): The Big-Five Personality Dimensions and Entrepreneurial Status: A Meta-Analytical Review. Journal of Applied Psychology, 91, 259-271.

Zhao, Hao, Scott E. Seibert, and G.T. Lumpkin (2010): The Relationship of Personality to Entrepreneurial Intentions and Performance: A MetaAnalytic Review. Journal of Management, 36, 381-404. 


\section{Appendix: Tables}

Table A1: Definition of variables

\begin{tabular}{|c|c|}
\hline Variable & Description \\
\hline Self-employment & Dummy = 1 if respondent was self-employed in 2009; else $=0$ \\
\hline $\begin{array}{l}\text { Entrepreneurial environment } \\
\text { Agglomerations } \\
\text { Urbanized regions } \\
\text { Rural areas }\end{array}$ & $\begin{array}{l}\text { Areas with high population density } \\
\text { Areas with moderate population density } \\
\text { Areas with low population density }\end{array}$ \\
\hline $\begin{array}{l}\text { Human capital } \\
\text { Years of education } \\
\text { Years of unemployment }\end{array}$ & $\begin{array}{l}\text { Number of years the respondent has been in full-time education } \\
\text { Number of years unemployed }\end{array}$ \\
\hline $\begin{array}{l}\text { Social capital } \\
\text { Either parent has been self- } \\
\text { employed }\end{array}$ & $\begin{array}{l}\text { Dummy = } 1 \text { if either parents was self-employed when the } \\
\text { respondent was } 15 \text { years old }\end{array}$ \\
\hline Father's occupation & $\begin{array}{l}\text { Father's occupation (ISCO-88) when respondent was } 15 \text { years } \\
\text { old }\end{array}$ \\
\hline Married & Dummy $=1$ if respondent was married in $2009 ;$ else $=0$ \\
\hline $\begin{array}{l}\text { Socio-demographic characte } \\
\text { Male } \\
\text { German citizenship } \\
\text { Age }\end{array}$ & $\begin{array}{l}\text { Dummy }=1 \text { if respondent is male; else }=0 \\
\text { Dummy }=1 \text { if respondent is German citizen; else }=0 \\
\text { Years of age }\end{array}$ \\
\hline $\begin{array}{l}\text { Personality characteristics } \\
\text { Openness to experience }\end{array}$ & $\begin{array}{l}\text { Mean score on the 7-point scales for: } \\
\text { "I see myself as someone who has an active imagination" } \\
\text { "I see myself as someone who is original and comes up with } \\
\text { new ideas" } \\
\text { "I see myself as someone who values artistic experiences" }\end{array}$ \\
\hline Extraversion & $\begin{array}{l}\text { Mean score on the 7-point scales for: } \\
\text { "I see myself as someone who is communicative, talkative" } \\
\text { "I see myself as someone who is outgoing, sociable" } \\
\text { "I see myself as someone who is reserved" (reversed) }\end{array}$ \\
\hline Conscientiousness & $\begin{array}{l}\text { Mean score on the 7-point scales for: } \\
\text { "I see myself as someone who does a thorough job" } \\
\text { "I see myself as someone who tends to be lazy" (reversed) } \\
\text { "I see myself as someone who does the things effectively and } \\
\text { efficiently" }\end{array}$ \\
\hline
\end{tabular}

Agreeableness Mean score on the following 7-point scales:

"I see myself as someone who is somewhat rude to others" (reversed)

"I see myself as someone who has a forgiving nature"

"I see myself as someone who is considerate and kind to others"

Neuroticism

Mean score on the 7-point scales for

"I see myself as someone who worries a lot"

"I see myself as someone who gets nervous easily"

"I see myself as someone who is relaxed, handles stress well" (reversed)

Risk propensity

An 11-point scale based on the question: "Are you generally a person who is fully prepared to take risks or do you try to avoid taking risks?" The value 0 means "risk averse" and the value 10 means "fully prepared to take risks." 
Table A2: Correlation matrix

\begin{tabular}{|c|c|c|c|c|c|c|c|c|c|c|c|c|c|c|c|c|c|}
\hline & & 1 & 2 & 3 & 4 & 5 & 6 & 7 & 8 & 9 & 10 & 11 & 12 & 13 & 14 & 15 & 16 \\
\hline 1 & Self-employed (yes $=1$, no $=0$ ) & 1 & & & & & & & & & & & & & & & \\
\hline 2 & Agglomerations & 0.048 & 1 & & & & & & & & & & & & & & \\
\hline 3 & Urbanized regions & -0.039 & -0.769 & 1 & & & & & & & & & & & & & \\
\hline 4 & Rural regions & -0.016 & -0.385 & -0.295 & 1 & & & & & & & & & & & & \\
\hline 5 & Years of education & 0.169 & 0.122 & -0.082 & -0.063 & 1 & & & & & & & & & & & \\
\hline 6 & Years of unemployment & -0.026 & -0.072 & 0.019 & 0.081 & -0.16 & 1 & & & & & & & & & & \\
\hline 7 & $\begin{array}{l}\text { Either parent self-employed } \\
(\text { yes }=1, \text { no }=0)\end{array}$ & 0.111 & 0.045 & -0.033 & -0.02 & 0.102 & -0.057 & 1 & & & & & & & & & \\
\hline 8 & Married $($ yes $=1$, no $=0)$ & 0.057 & 0.004 & -0.006 & 0.002 & 0.019 & -0.074 & 0.009 & 1 & & & & & & & & \\
\hline 9 & Male $($ yes $=1$, no $=0)$ & 0.091 & 0.001 & -0.001 & -0.0002 & 0.023 & -0.022 & -0.007 & 0.031 & 1 & & & & & & & \\
\hline 10 & German (yes = 1, no = 0) & 0.012 & -0.057 & 0.041 & 0.026 & 0.113 & -0.07 & -0.009 & -0.056 & 0 & 1 & & & & & & \\
\hline 11 & Age & 0.182 & 0.016 & -0.019 & 0.004 & 0.06 & 0.02 & 0.031 & 0.315 & 0.042 & 0.069 & 1 & & & & & \\
\hline 12 & Conscientiousness & 0.031 & -0.022 & 0.01 & 0.019 & -0.071 & -0.011 & -0.018 & 0.058 & -0.082 & -0.021 & 0.109 & 1 & & & & \\
\hline 13 & Extraversion & 0.056 & 0.021 & -0.014 & $-0.011-$ & -0.033 & -0.034 & 0.012 & -0.016 & -0.144 & -0.014 & -0.059 & 0.158 & 1 & & & \\
\hline 14 & Agreeableness & 0.006 & 0.007 & -0.004 & -0.004 & 0.031 & 0.004 & -0.015 & -0.01 & -0.149 & -0.013 & 0.009 & 0.259 & 0.073 & 1 & & \\
\hline 15 & Openness & 0.123 & 0.06 & -0.037 & -0.036 & 0.165 & -0.041 & 0.049 & -0.044 & -0.088 & 0.001 & 0.04 & 0.11 & 0.331 & 0.137 & 1 & \\
\hline 16 & Neuroticism & -0.064 & -0.022 & 0.019 & 0.006 & -0.084 & 0.051 & -0.011 & 0.006 & -0.201 & -0.015 & -0.056 & -0.099 & -0.133 & -0.102 & -0.023 & 1 \\
\hline 17 & Willingness to take risks & 0.082 & 0.027 & -0.026 & -0.003 & 0.031 & -0.004 & 0.033 & -0.075 & 0.178 & -0.02 & -0.12 & -0.09 & 0.162 & -0.134 & 0.154 & -0.143 \\
\hline
\end{tabular}


Table A3: Descriptive statistics

\begin{tabular}{|c|c|c|c|c|c|}
\hline Variable: & Mean & Median & Minimum & Maximum & $\begin{array}{l}\text { Standard } \\
\text { deviation }\end{array}$ \\
\hline Self-employed $($ yes $=1$, no $=0$ ) & 0.124 & 0 & 0 & 1 & 0.329 \\
\hline Agglomerations & 0.501 & 1 & 0 & 1 & 0.500 \\
\hline Urbanized regions & 0.370 & 0 & 0 & 1 & 0.483 \\
\hline Rural regions & 0.129 & 0 & 0 & 1 & 0.335 \\
\hline Years of education & 12.871 & 12 & 7 & 18 & 2.696 \\
\hline Years of unemployment & 0.603 & 0 & 0 & 23.8 & 1.540 \\
\hline $\begin{array}{l}\text { Either parent self-employed (yes } \\
=1, \mathrm{no}=0 \text { ) }\end{array}$ & 0.103 & 0 & 0 & 1 & 0.303 \\
\hline Married $($ yes $=1$, no $=0$ ) & 0.614 & 1 & 0 & 1 & 0.487 \\
\hline Male $($ yes $=1$, no $=0$ ) & 0.525 & 1 & 0 & 1 & 0.499 \\
\hline German $($ yes $=1$, no $=0)$ & 0.954 & 1 & 0 & 1 & 0.210 \\
\hline Age & 43.005 & 43 & 18 & 84 & 10.723 \\
\hline Openness & 4.472 & 4.333 & 1 & 7 & 1.163 \\
\hline Conscientiousness & 5.892 & 6 & 1.667 & 7 & 0.878 \\
\hline Extraversion & 4.841 & 5 & 1 & 7 & 1.149 \\
\hline Agreeableness & 5.260 & 5.333 & 1 & 7 & 0.974 \\
\hline Neuroticism & 3.710 & 3.667 & 1 & 7 & 1.206 \\
\hline Willingness to take risks & 4.104 & 4 & 0 & 10 & 2.076 \\
\hline
\end{tabular}

